https://doi.org/10.18485/dpls_pld.2020.6.ch4

811.163.42’42

\author{
Ana Mikić Čolić, Ivana Trtanj \\ J. J. Strossmayer University of Osijek
}

\title{
DISCOURSE COMPETENCE OF SPEAKERS OF CROATIAN AS A FOREIGN LANGUAGE
}

\begin{abstract}
With the emergence of actual syntax, systemic functional theory and functional grammar by M. A. K. Halliday and text linguistics, the perspective on grammar changed and was directed from a text to a sentence. The focus was on knowledge that enables every speaker to connect linguistic elements of lower order into coherent written or spoken text. This knowledge is called discourse competence. This paper examines discourse competence of speakers of Croatian as a foreign language, i.e. its components - cohesion and coherence - that are realized through different lexical, grammatical and semantic elements. The analysis of discourse competence components will be conducted on the corpus of 34 texts written by non-native speakers whose knowledge of Croatian was assessed as B1 level.
\end{abstract}

Key words: text, discourse, linguistic competence, discourse competence, cohesion, coherence

\section{Introduction}

The term competence has been a staple in linguistics since mid20th century. Chomsky, who is credited with introducing it, took it to mean abstract linguistic knowledge, to be theoretically distinguished from use (performance). Critics were quick to note that the concept of linguistic competence excludes sociological and psychological aspects of posessing linguistic knowledge. Putting the speaker who posesses not only grammatical knowledge of language but also knowledge of its proper use in the centre of linguistic interest resulted in the notion of communicative competence, credited to Del H. Hymes. Communicative competence thus consists of grammatical competence, which represents the knowledge of 
grammar rules, and performative competence (performance), relating to the command of rules on the use of language (Hymes 1972). Ever since, the terms linguistic and communicative competence have intersected, with a very frequent overlap in various readings between the terms linguistic and grammatical competence. A more detailed look into different conceptions of gramatical competence reveals the fact that the phonological, morphological, syntactic and lexical components are present in all models of grammatical competence, whereas only some are supplemented by aspects of discourse and pragmatic competence. Bachman (1990), Bachman and Palmer $(1996,2010)$ as well as Pavičić Takač and Bagarić Medve (2013) separate dicourse and pragmatic competence from grammatical competence and subsume the three competences under the term linguistic competence.

This paper relies on a corpus of 34 texts procduced by native speakers of German, Polish, Czech, Spanish, Ukranian/Russian and English, whose command of Croatian was assessed at B1 level, to analyze the use of structural elements which make a text a text, with special emphasis on the use and range of cohesive devices and the organization of the sentences, the content, and flow of ideas inside the text.

\section{Discourse competence}

Discussions on grammatical competence on the one hand and pragmatic competence on the other often tend to disregard equal importance of the knowledge required by the speaker to connect lowerlevel linguistic elements (words, sentences) into a full and meaningful written or oral text. The latter knowledge is dubbed discourse competence and commonly defined as command of ways to connect and interpret linguistic forms and meanings to achieve a meaningful and complete written or spoken texts of different genres (Canale 1983). A definition of discourse competence is also provided by the Common European Framework for Languages ${ }^{1}$ (2005), which defines it as the ability of language learners and users to string sentences together to produce coherent linguistic units. Furthermore, the CEFL includes knowledge and capacity of sentence ordering in accordance with the topic/basic ideas in written and oral discourse, the ability to structure and manage discourse in line with topical organization, intended activities and connectedness, logical

\footnotetext{
${ }^{1}$ Henceforth CEFL.
} 
ordering, syle, register and rhetorical efficiency, as well as the awareness of text planning conventions pertinent in a community. Speakers' abstract linguistic competence addressed at the beginning of the previous section did not assume linguistic use as a default. The text as the basic unit of the linguistic system, the basic information and communication unit and the basic unit of language activity (Glovacki-Bernardi 2004: 5) had thus often eluded systematic linguistic description. Such views saw a radical change with the emergence of three approaches to language based on the idea of the Prague School of Linguistics, which put text in focus: Actual syntax, M. A. K. Halliday's Systemic-Functional theory and Text Linguistics (Badurina 2007; 2016). The three approaches started paying attention to the communicative function of language, which automatically implied a shift of interest from lower-level units of linguistic description (phoneme, morpheme, lexeme, sentence) to text, which started being defined as that which results from linguistic action and is turned into language through the speakers' linguistic creativity (Glovacki-Bernardi 2004: 19).

The text thus presupposes the notion of structure with seven components contributing to it: cohesion, coherence, intentionality, acceptability, informativeness, situatedness, and intertextuality (de Beaugrande and Dressler 1981: 7). Cohesion and coherence are textoriented, whereas the other five constitutive principles are oriented towards the participants in a communicative act. Due to their complexity and the crucial role played in the definitions and theories of textness, we pay additional attention to cohesion and coherence in the following sections.

\subsection{Cohesion}

Dictionaries define cohesion as the 'relation, a connection of thoughts', whereas cohesion is defined as 'relation, connection, congruence, interrelatedness' (Anić, Klaić, Domović 2002: 701). Text cohesion is reflected in relations between sentences/utterances and is achieved by cohesive devices. Halliday and Hasan (1976) suggest that the status of collection of sentences as a text depends on the cohesive relation within and between sentences, which in turn creates texture. Their interpretation of cohesion is specific for the crucial role the latter plays in the meaning interpretation of a text. The text has texture and it is this, the two authors claim, that distinguishes it from something that is not a text. 
In Badurina's (2007) view, cohesion refers to ways the surface structure components of the text, i.e. the words we hear or read, are interconnected in a sequence, whereby, she maintains, the surface components depend on one another in accordance with grammatical patterns and conventions. One can thus claim that cohesion depends on grammatical dependencies. In other words, it is reflected in relationships between sentences, i.e. utterances within a text, and achieved by lexical and syntactic means.

\subsection{Coherence}

Unlike cohesion, which rests on grammatical dependencies and pertains to components of the surface structure of a text (words we see or hear), the property of cohesion is identified in the relatedness between sentences within a text, which results from cognitive processes, i.e. mental activities of interlocutors (Badurina 2007). Coherence thus concerns logico-semantic relations between sentences/utterances recognized by participants in the communicative process and can therefore be defined as a subjective phenomenon. Hobbs (1979:67) subscribes to such a view of coherence, claiming that is primarily motivated by the speaker's need to be understood by the interlocutor. To grasp the point of the text, its recipient must necessarily rely both on his/her own experience with a certain text type, and on facts provided by the context. Badurina (2007) adds that it is the cohesiveness of the text that largely contributes to its coherence, a view supported by many other scholars. The overview of definitions of coherence leads us to conclude that it most frequently relates to syntacticsemantic relations between sentences and other linguistic elements in a string of sentences and constitutes an integral whole with cohesion in the process of structuring a text.

\subsection{Research into text cohesion and cohesion in L2 speakers}

Research into cohesion and coherence in L2 speakers proves to be quite scarce. Of the (more) relevant studies, most are devoted to cohesion, i.e, the use of connecting devices in written texts. Research into the use of connectors in texts of L2 speakers of English has shown that, in comparison to native speakers, non-native speakers use certain connectors too frequently or incorrectly, i.e. use these in places where they are superfluous, or in places which prompt an incorrect understanding of 
a text as a whole (e.g. Chen 2006). Studies of the use of connectors in texts by L2 speakers of German as a foreign language by Bagarić Medve and Čelebić (2012) as well as Pavičić Takač and Bagarić Medve (2013) also found that learners overuse certain connectors, often those typical of lower levels of language proficiency. A similar analysis done on written assignments of Hungarian students of English (Tankó, 2004) yielded similar results, confirming lower proficiency and use of connectors.

\section{Research into text cohesion ans coherence in $\mathbf{L} 2$ speakers of Croatian}

Research into text cohesion and coherence in L2 speakers of Croatian done for the purposes of this paper was carried out as part of the project Coherence of written text in L2: Croatian, German, English, French and Hungarian language in comparison, conducted since 2017 at the Faculty of Humanities and Social Sciences in Osijek. ${ }^{2}$

\subsection{Methodology}

A written production task was developed within the project to analyze features of text coherence in L2 speakers of Croatian, as well as the factors which influence text (in)coherence in L2. Participants were asked to write an essay on an assigned topic, where they would approach the topic critically, voice their opinion and elaborate on it. The length of the essay was set at 150-180 words and the topic was Life in a city. The research was conducted in December 2017.

Apart from the essay and informed consent form, students were asked to fill a questionnaire specifying their personal data (age, gender, study programme) and information on their mother tongue, the time span of learning Croatian and staying in Croatia. They were also asked to evaluate the level of their skills and command of the Croatian language at different levels of speech and text production on a scale from 1 (very low) to 5 (very high). The questionnaire data will serve as variables in the analysis of results.

\subsection{Subjects}

The corpus consists of 34 essays. The command of Croatian for all participants was evaluated as B1 in accordance to the CEFL. All participants

2 The project is (co-)financed by the Croatian Science Foundation (IP-2016-06-5736). 
were students, falling into several programmes: Southeast European Studies, Law, Political Sciences, History, Economics and Philological Studies. 12 male students and 22 female students participated in the study, with an average age of 23. Their mother tongues are German (10), Polish (5), English (16), Czech (1), Spanish (1) and Russian/ Ukranian (1).

\subsection{Goals}

The study aims to analyze the connection between the use of cohesive devices and the level of text coherence in L2, as well as to test if there are differences in the features and manner of achieving text coherence attributable to personal characteristics of L2 users (formal vs. informal context of mastering L2, mother tongue). Finally, the study tests the use and range of cohesive devices and organization of content, sentences and sequencing of ideas in a text.

\subsection{Results and discussion}

A user ranked B1 according to the CEFL is able to understand the main ideas of clear standard speech on familiar topics encountered daily at work, at school or in free time. S/he is capable of handling most situations encountered while travelling through an area where the language is spoken. Furthermore, the speaker is able to produce a simple connected text on a familiar topic or one of personal interest, describe experiences and events, personal dreams, hopes and desires, and briefly elaborate on personal views and plans. The topic assigned in this study is, therefore, in complete accordance with the participants' level of language command, since it presupposes that the user, i.e. subject, can speak/write about the contemporary way of life, social networks, life quality, reasons for hapiness...

Apart from text cohesion and coherence, the following analysis is set to address the issue of text variety, the subjects' ability to finish the text, as well as their vocabulary range, command of ortography and grammar rules. The elements are analyzed due to their presumed importance for the production of a cohesive and coherent text. The aspects are analyzed in the following sections with respect to standardized descriptors, whereby participants are awarded marks 0 (does not match the descriptor), 1 (very poor match with the descriptor), 2 (poor match with the descriptor), 3 (partial match with the descriptor) 4 (significant match with the descriptor) and 5 (full match with the descriptor). 


\subsubsection{Task completion and text type}

Two elements served as basis for evaluating task completion: text length and appropriate elaboration of all parts of the assigned topic. Since the task was translated into the subjects' respective mother tongues and they were all instructed as to the purpose of the task, the participants almost fully (97\%) met the assigned word count in all 34 essays. The results are somewhat weaker with regards to proper elaboration of the topic. Regarding the latter, special attention was paid to the evaluation of equal elaboration of the introduction and the conclusion, as well as arguments for and against the assigned topic. The average grade of this aspect is somewhat lower at 4.25 , which means that most participants failed to properly elaborate a part of the topic. This primarily concerns the introductory part, which is whittled down to a single sentence:

(1) Život u gradu može imati puno prednosti, ali i nedostataka.

Some essays completely lack an introduction. The participants thus introduce the topic using sentences which can not be considered as introductory to the assigned topic, e.g.

(2) Ja sam uvijek živjela u gradovima. Madrid je glavni grad i tako velik sa oko 3 milijuna stanovnika.

Success in task completion had a direct effect on the descriptors used to evaluate the text type criterion. Uneven elaboration of one essay part had thus had a detrimental effect on the descriptor related to adherence to conventions of essay writing and formation in a language or culture, with the avaerage grade for this descriptor amounting to 4,06. Special attention in the evaluation of this aspect of the essay was paid to the proper formation of introduction, body and conclusion, as well as their visual separation, with an average grade of 3.75. The subjects tended to finish the essay as soon as they met the required word count, which meant finishing the essay without properly rounding off the topic, i.e. ending the essay by stating the pro/ counterarguments regarding the topic, e.g.

(3) Međutim, to je sam nedostatak života u Jeni i nije velik problem. Putujem samo ponekad i kada putujem, imam vrijeme često. 


\subsubsection{Vocabulary and grammar}

According to the descriptive frame of B1 level reference point (Grgić, Gulešić Machata, Nazalević Čučević 2013), speakers at that level are able to express their opinions or views in Croatian, analyze them into parts, agree or disagree with a statement and express different levels of (dis)agreement.

The vocabulary criterion was evaluated using three descriptors: the vocabulary range for the task is broad, vocabulary is adequately used, as are ortographic norms. The participants' vocabulary range was graded rather high, at 4.56 . The descriptor pertaining to proper use of vocabulary also scored high at 4.43 . Vocabulary errors are most frequently related to incorrect use of verbs, as illustrated in the following examples:

(4) Ako ti si student, na primjer, ti imaš puno aktivnosti da možeš trajati u gradu...

(5) U današnjeg dana uvjek mnogo ljudi ulazi iz sela u grad. or to an entirely inappropriate use of a word as exemplified in

(6) To znaći da okrasti u gradu može se ići u zoologski vrt...

The high vocabulary result of $\mathrm{L} 2$ speakers of Croatian at B1 level can be accounted for by the fact that vocabulary acquisition is often regarded as more important than acquistion of grammatical stractures, especially in communicative, i.e. functional approaches to second language teaching. For a lexical unit to become a part of a L2 learner's active vocabulary it also needs to be acquired in its syntactic sense, i.e. the learner should know how each unit fits into a sentence (Udier 2009). The high vocabulary result of L2 speakers of Croatian at B1 level also confirms that the assigned essay topic was well-chosen, i.e. that due attention was paid to the criteria pertaining to introduction of vocabulary in L2 teaching, viz. word frequency, their gradual introduction, simplicity and concreteness.

The errors spotted in the course of vocabulary analysis are predominately related to swapping of sounds, particularly those close with respect to their place of articulation, which results in a lexical, i.e. semantic error:

(7) ... kad želiš imati najviše obrazovanje moraš odići u grad na fakultet.

or the utilized word formally (or semantically) closely resembles the word intended in the sentece. 
(8) ... u mladosti je idealno živjeti u gradu i uživati u brzom i uzbuđenom životu.

The most interesting decriptor in terms of vocabulary is the appropriately used spelling convention, which was also the lowest graded descriptor related to the criterion, at 4.2. According to the CEFL (2005) a B1 speaker is capable of producing a connected text which is normally fully intelligible, with ortography, puntctuation and text layout sufficiently correct for the text to be sufficiently followed. The lower average grade of this descriptor can be interpreted by the fact that ortography tends to be quite neglected in teaching Croatian as a foreign language, with no place for ortography-related topics in course books for teaching Croatian as L2 (Grgić, Udier 2012). The participants' most common sources of errors were the realization of the jat-reflex and sounds, and $d \check{z}, d$ :

(9) ... što ljudi sjedi cjeli dan kod kuće, na primjer tinejđeri...

(10) Izbor znaći da imaš slobodu...

(11) Neki smatraju da je život u gradu ljep i dobar, i hoče da žive u gradu.

Examples (9) - (11) seem to indicate that ortographic competence of participants is not at B1 level, since it presupposes a correct distribution of those sounds in words familiar to speakers. On the other hand, the fact that native speakers also have problems with the distribution of these palatals ${ }^{3}$ leads us to take the assumption of ortographic (in)competence of participants with a grain of salt. Errors are also found in the use of punctuation, with $\check{z}$ used in place of $z$, as well as an incorrect use of the sound $n j$ :

(12) Mnogo ljudi imaju ražlićete mišljene o život u gradu.

These errors also fit existing descriptions and analyses ${ }^{4}$ of writing at B1, which clearly calls for a change and adjustment of glotodidactic materials in view of the results of such analyses. The participants also had problems with the uncompound spelling of words, most frequently the negation ne:

(13) Oduvijek sam željela imati konja, ali to je bilo ne moguće jer sam živjela u stanu.

\footnotetext{
${ }^{3}$ Škarić's research (2006: 204) suggests that "by ear č-ć is distinguished only a fraction better than by pure guesswork $(53.2 \%$; guesswork $50 \%)$..."

${ }^{4}$ On the issue, see Grgić, Udier (2012).
} 
The criterion of grammaticality was tested using two descriptors: a wide range of syntactic structures and the correct use of morphosyntactic norm. Similar to ortography, grammar also scored poorly. The range of syntactic structures scored 4.2 and the correctness of morphosyntactic form art 3.7, implying that participants only partially followed the grammatical norm. Due to morphological complexity of Croatian, the B1 level still shows a dominance of morphology over syntax. However, new language goals slowly shift towards the complex sentence and connecting of main and dependent clauses, as well as to connecting sentences into a text and to text cohesion as a whole (Grgić, Gulešić Machata, Nazalević Čučević 2013).

The most common mistakes concern wrong use of cases, as exemplified in

(14) Često ljudi koji žive u selima imaju čvrsti odnosi.

(15) ... ne možemo se vraćati u prošlog vremena.

One example featured the inability to distinguish the category of animacy in masculine gender accusative case.

(16) ... puno ljudi mogu imati raka pluća.

Any instructor of Croatian as L2 knows the case system to be the most demanding grammar area, as well as one most difficult to master. What contributes to a low motivation to master this area is the attitude that Croatian can be spoken well even without the command of its morphology. The latter lead to a stand that one should rely on the grammatical-semantic approach, which includes elabrorating on what cases are, their roles and meanings. Surface cases are thus learned gradually and continuously related to deep cases, and one also learns prepositions and verbs which go together specific surface cases (Udier, Gulešić Machata, Čilaš-Mikulić 2006). Such approach would facilitate acquisition and understanding of the issue to all learners, particularly those whose mother tongues lack cases, who must therefore acquire a completely new grammatical concept.

A futher insight from the evaluation of grammatical level of written texts concerns the overuse of certain adverbs. Coursebooks for teaching Croatian and a foreign language do not handle adverbs as a separate word class. Their acquisition is rather understood as part of vocabulary acquisition (Musulin, Macan 2006). Previous research ${ }^{5}$ has suggested

\footnotetext{
${ }^{5}$ See Musulin, Macan (2006) on the issue.
} 
quantifying adverbs as the most frequent subclass, which is corroborated by our study:

(17) Život u gradu ima puno prednosti i naravno puno nedostataka. (...) Puno je mogućnosti, (...). Ljudi imaju puno mogućnosti (...). Možemo vidjeti da život u gradu ima mnogo prednosti, (...), zato što puno ljudi (...).

Apart from the overuse of the adverb puno, the above example points to a loss of distinction between the adverbs puno (a lot of) i mnogo (much/many), which has obviously began to spill over from vernacular language to general use.

Furthermore, participants make errors in form, most frequently by using the wrong suffix:

(18) ... onda može trenirati u sportivnih klubova.

(19) ... može se ići u zoologski vrt.

(20) Lakšije je upoznati nove osobe...

Developed morphology of verbs results in errors in the formation of the word class:

(21) Osječam se bolje na selu, gdje mogu trčiti, šetati i hodati...

The examples illustrate that participants compensate for their incomplete knowledge of morphology by resorting to analogy in formation.

Completely ill-formed (subordinate) clauses are extremely rare:

(22) Izbor znaći da imaš slobodu i da nema obavezu da živjeti kao ne hočes živjeti.

A separate category of grammatical errors is made up of those that occur under the influence of the mother tongue. Such deviations are known as transfer-based.The attitude towards these has changed several change in contemporary history of glotodidactics. They were first considered to be "errors", i.e. signs that learners have not sufficiently mastered a language. Most deviations had later begun to be ascribed to the influence of L1 only to be nowadays considered a vanilla component of the interlanguage ${ }^{6}$ and a ubiquitous part of language acquisition process (Gulešić Machata 2013).

(23) U gradu je stress (...). Puno ljudi ima depressije.

(24) ... kada živiš i radiš u metropolis. Previše ljudi, previše autos...

${ }^{6}$ The term presupposes the coexistance of parallel linguistic codes. 


\section{(25) Nije atractivni...}

(26) ... ljudi samo bacaju svoj garbić u vodi...

In example (23) a native speaker of German transfers the spelling of the words stres and depresija from German. Example (24) illustrates the influence of Spanish, whereas in examples (25) and (26) speakers of English transfer ortographic and lexical elements of their native tongue into an interlingual - English-Croatian - area.

\subsubsection{Cohesion and coherence}

The cohesion criterion was tested based on the following questions: how do participants use cohesive devices in the text and what is the range of the cohesive devices used? The criterion relies on two descriptors: the use of cohesive devices to connect paragraphs and sentences is appropriate and efficient, with the range of of appropriately used cohesive devices broad enough for the task. The evaluation pertaining to the first descriptor therefore focused on an appropriate and functional use of cohesive devices such as personal pronouns, subordinate clause conjunctions etc., whereas the focus for the other descriptor is put on the diversity of the cohesive devices used.

The analyzed essays confirm the insights from previous studies of cohesive devices referenced in the theoretical part of the paper, viz. the overuse of a specific cohesive device. In this study it is the conjunction $i$ as illustrated in the following examples:

(27) ... zato što su stanarine u gradu više i plaće se $\underline{\mathbf{i}}$ više za manje prostora. $\underline{\mathbf{I}}$ dobra infrastruktura nema samo prednosti. (...)

I puno ljudi produciraju i puno smeća.

One participant tended to use the conjunction ali, not only excessivly, but also incorrectly:

(28) Ali zašto oni ovo radi? (...) Ali život u gradu ima takođe nedostatki... Ali najviša problema... (...) Na selu ali ima vrlo mnogo posla... (...) Ali se ne može baviti svaki dan...

In total, however, the participants did very well with respect to cohesion. The average result of the first descriptor - appropriate and efficient use of cohesive devices - stood at 4.4, whereas the second marker - a wide range of cohesive devices - received an average score of 4.3. The 
scores confirm that most participants do show a fine command of cohesive devices with respect to their language level.

The coherence criterion pertains to the following question: how is the content of the text organized and is there a logical flow of thoughts and sentences? In the evaluation of the text with respect to the first descriptor - the logical organization of content and sentences - we observed whether the content on the level of the full text was organized in a logical way, i.e special attention was paid to global coherence. The average grade for this descriptor was very high, at 4.5 . This means that the participants organized the content at the level of the whole in a fully logical way, the individal text components (introduction, body, conclusion) complement each other in a logical way and all parts contain the expected requirements, i.e. the introduction does introduce an opinion, there is no mixing of of conclusion(s) with arguments in the body, and the latter does not simultaneously and confusingly cover both advantages and disadvantages with respect to the assigned topic. This descriptor is supplemented by the second one, related to a comprehensible flow of thoughts and sentences, which was also scored at 4.5. Regarding this descriptor, special attention was paid to local coherence, i.e. the degree to which thoughts and sentences exhibit a logical flow, if the text reads easily, i.e. whether the sentence content follows from the content of the previous one, or the (not too distant) context. The analysis also focused on the connecting of sentences between paragraphs. A very high score in text coherence again confirms that the task was well set. The assigned topic - life in the city had allowed a regular development of semantic progressions and resulted in meaningful, coherent and grammatically cohesive texts.

\section{Conclusion}

The study presented above has conformed the current insights in cohesion and coherence outlined in the introductory sections of the paper. These relate cohesion to the surface (grammatical, lexical, ortographic) structure of the written text and see is as a prerequisite to achive coherence, i.e. relatedness between sentences in a text, which results from cognitive processes, i.e. the speaker's/ subjects mental activities. This relatedness is confirmed by average scores of cohesion and coherence in participants, which are almost identical: on average, cohesion was rated at 4.4, and coherence at 4.5. 
A look at individual student scores immediately reveal the lowest average scores in the native speaker of Spanish, who scored 3.3 in task completion, vocabulary and grammar, with cohesion and coherence coming at an even lower 2.63. Such results also match all previous research and theories of foreign language learning. The causes of lower results should probably be attributed he fact that Spanish belongs to a genetically different language family.

The highest scores, on the other hand, were recorded in native speakers of a genetically related native language, viz. Polish, scoring an average 4.8 .

At this point, we should also note the findings related to another variable, viz. a stay in Croatia. It was the students who participated in the study during their stay in Croatian on an Erasmus scholarhip who scored best on average. This can be attibuted to both their intrinsic motivation, i.e. desire to integrate with native speakers of Croatian, and to the extrinsic motivation, i.e. obligation of attending courses and taking exams in Croatian.

Despite the lower scores in some components, the results do suggest that discourse competence of participants does match their level of knowledge of Croatian. A developed discourse competence has resulted in well-ordered sentence management, well-suited to the topic and main ideas, the logical ordering, style, register and rhetorical efficiency.

In conclusion, research such as this, as well as its results, should not be self-serving, but should instead be seriously considered in the planning of the coursebooks, practice books and other manuals intended for teaching Croatian as a foreign language. The "resilience" of some deviations recorded in participants calls for a revision of existing glododidactic materials, as well as their adjustment with the theoretical insights in the field, and the contemporary way of life and education.

\section{References}

Anić, V., Klaić, N. and Ž. Domović (2002). Rječnik stranih riječi. Zagreb: Saniplus.

Bachman, L. F. (1990). Fundamental Considerations in Language Testing. Oxford: Oxford University Press.

Bachman, L. F. and A. S. Palmer (1996). Language Testing in Practice: Designing and Developing Useful Language Tests. Oxford: Oxford University Press. 
Bachman, L. F. and A. S. Palmer (2010). Language Assessment in Practice. Oxford: Oxford University Press.

Badurina, L. (2007). Od sintakse prema suprasintaksi - dvosmjerno. In: Sintaktičke kategorije (B. Kuna, ed.), Osijek: Filozofski fakultet, 9-21.

Badurina, L. (2016). Jezikoslovni pristupi tekstu, Croatica XL, 60: 49-61.

Bagarić Medve, V. and I. Čelebić (2012). Bewertung der Diskurskompetenz: holistischer vs. analytischer Ansatz. In: Applied Linguistics Today: Research and Perspectives - Angewandte Linguistik heute: Forschung und Perspektiven (L. Pon, V. Karabalić and S. Cimer, eds.), Frankfurt: Peter Lang, 33-49.

Beaugrande, R. de and W. Dressler (1981). Introduction to text linguistics. London: Longman.

Canale, M. (1983). From communicative competence to communicative language pedagogy. In: Language and Communication (J. C. Richards and R. W. Schmidt, eds.), 2-27.

Celce-Murcia, M., Dörnyei, Z. and S. Thurrell (1995). Communicative Competence: A Pedagogically Motivated Model with Content Specifications, Issues in Applied Linguistics, 6 (2): 5-35.

Chen, C. W. 2006. The use of conjunctive adverbials in the academic papers of advanced Taiwanese EFL learners, International Journal of Corpus Linguistics, 11 (1): 113-130.

Glovacki-Bernardi, Z. 2004. O tekstu. Zagreb: Školska knjiga.

Grgić, A., Gulešić Machata, M. and I. Nazalević Čučević (2013). Hrvatski B1: opisni okvir referentne razine $B 1$. Zagreb: FF press.

Grgić, A. and S. L. Udier (2012). Pravopisna kompetencija na razini B1 u hrvatskome kao inome jeziku, Lahor 14: 204-220.

Gulešić Machata, M. (2013). Apriorna analiza odstupanja u gramatičkom rodu (s obzirom na prvi jezik učenika), Opera Slavica, XXIII, 4: 174-186.

Halliday, M. A. K. (1975). Learning how to Mean (Explorations in the Development of Language). London: Edward Arnold.

Halliday, M. A. K. and R. R. Hasan (1976). Cohesion in English. London: Longman.

Hobbs, J. R. (1979). Coherence and Coreference, Cognitive science 3: 67-90.

Hymes, D. H. (1972). On communicative competence. In: Sociolinguistics (J. B. Pride and J. Holmes eds.), 269-293.

Musulin, M. and Ž. Macan (2006). Usvajanje priloga u inojezičnome hrvatskome, Lahor 2: 176-189.

Pavičić Takač, V. and V. Bagarić Medve (2013). Jezična i strategijska kompetencija u stranome jeziku. Osijek: Filozofski fakultet.

Škarić, I. (2006). Hrvatski govorili!. Zagreb: Školska knjiga. 
Tankó, G. (2004). The use of adverbial connectors in Hungarian university students' argumentative essays. In: How to Use Corpora in Language Teaching (J. Sinclair, ed.), John Benjamins, 157-181.

Udier, S. L. (2009). Pristup obradi leksičkih jedinica u nastavi hrvatskoga kao drugoga i stranoga jezika, Lahor 7: 77-93.

Udier, S. L., Gulešić Machata, M. and M. Čilaš-Mikulić (2006). Gramatičkosemantički pristup obradi padeža, Lahor 1: 36-48.

Zajednički europski referentni okvir za jezike: učenje, poučavanje, vrednovanje (2005). Zagreb: Školska knjiga.

Ana Mikić Čolić, Ivana Trtanj

\section{DISKURSNA KOMPETENCIJA INOJEZIČNIH GOVORNIKA HRVATSKOGA}

Sažetak: Pojavom pravaca aktualne sintakse, sistemske funkcionalne teorije i funkcionalne gramatike M. A. K. Hallidaya te lingvistike teksta sredinom 20. stoljeća mijenja se gramatička perspektiva te ona kreće od teksta prema rečenici. U središte pozornosti dolazi znanje koje govorniku omogućuje povezivanje jezičnih elemenata nižega reda (riječi, rečenice) u cjeloviti i smisleni pisani ili usmeni tekst. To znanje naziva se diskursna kompetencija. U ovome radu govorit će se o diskursnoj kompetenciji inojezičnih govornika hrvatskoga, odnosno o njezinim sastavnicama - koheziji i koherenciji - koje se ostvaruju različitim leksičkim, gramatičkim i semantičkim sredstvima. Analiza sastavnica diskursne kompetencije inojezičnih govornika hrvatskoga načinjena je na korpusu od 34 teksta koje su napisali neizvorni govornici čije je znanje hrvatskoga procijenjeno na B1 razinu.

Ključne riječi: tekst, diskurs, jezična kompetencija, diskursna kompetencija, kohezija, koherencija 